\title{
THE ECONOMIC IMPACT OF WATER TAXES: A COMPUTABLE GENERAL EQUILIBRIUM ANALYSIS WITH AN INTERNATIONAL DATA SET
}

Maria Berrittella ${ }^{a}$, Katrin Rehdanz ${ }^{b, *}$, Roberto Roson ${ }^{c, d}$ and Richard S.J. Tol ${ }^{b, e, f, g}$

${ }^{a}$ Centro Interdipartimentale di Ricerche sulla Programmazione Informatica dell'Economia e delle Tecnologie (CIRPIET), University of Palermo, Viale delle Scienze, 90128 Palermo, Italy

${ }^{b}$ Research Unit Sustainability and Global Change, Hamburg University and Centre for Marine and Atmospheric Science, Bundesstrasse 55 (Pavilion), 20146 Hamburg, Germany

${ }^{c}$ Department of Economics, University Ca' Foscari, Cannaregio S. Giobbe 873, 30121 Venice, Italy

${ }^{d}$ Fondazione Eni Enrico Mattei, Venice, Italy

${ }^{e}$ Economic and Social Research Institute, Dublin, Ireland

${ }^{f}$ Institute for Environmental Studies, Vrije Universiteit, Amsterdam, The Netherlands

${ }^{g}$ Engineering and Public Policy, Carnegie Mellon University, Pittsburgh, PA, USA

* Corresponding author:

E-mail: katrin.rehdanz@zmaw.de

Working Paper FNU-96 (revised)

\begin{abstract}
Water is scarce in many countries. One instrument to improve the allocation of a scarce resource is (efficient) pricing or taxation. However, water is implicitly traded on international markets, particularly through food and textiles, so that impacts of water taxes cannot be studied in isolation, but require an analysis of international trade implications. We include water as a production factor in a multi-region, multi-sector computable general equilibrium model (GTAP), to assess a series of water tax policies. We find that water taxes reduce water use, and lead to shifts in production, consumption, and international trade patterns. Countries that do not levy water taxes are nonetheless affected by other countries' taxes. Taxes on agricultural water use drive most of the economic and welfare impacts. Reductions in water use (welfare losses) are less (more) than linear in the price of water. The results are sensitive to the assumed ability to substitute other production factors for water. A water tax on production would have different effects on water use, production and trade patterns, and the size and distribution of welfare losses than would a water tax on final consumption.
\end{abstract}

Keywords: Computable General Equilibrium, Virtual Water, Water Allocation, Water Pricing, Water Scarcity

JEL Classification: D58, Q25, Q28 
Water is one of our basic resources, but it is often short. The total amount of fresh water available would be sufficient to provide the present world population with a minimally required amount of water. However, the uneven distribution of water and people among regions has made the adequate supply critical for a growing number of countries (Seckler, Amarasinghe, Molden, Silve \& Barker, 1998). Rapid population growth and increasing consumption of water per capita has aggravated the problem. Water withdrawal for most uses is projected to increase by at least $50 \%$ by 2025 compared to 1995 level (Rosegrant, Cai \& Cline, 2002). An additional reason for concern is climate change. Climate change models predict that geographic differences in rainfall are likely to become more pronounced with increased precipitation in high latitudes, and decreased rainfall elsewhere. Higher temperatures would imply larger water demand and higher evaporation (IPCC, 2001).

As the supply of water is limited, attempts have been made to economize on the consumption of water, especially in regions where the supply is critical. One way to address the problem is to reduce the inefficiencies in irrigation and urban water systems from existing water uses. In urban water systems, water is wasted through leakage. This is particularly pronounced for large cities in Africa, Asia, Latin America and even in the water-scarce Middle East (Rosegrant et al., 2002). Yet, in 2000 about 70\% of all water was used for agriculture. ${ }^{1}$ For some developing countries the average irrigation efficiency is far below what is technically possible. The current level and structure of water charges mostly do not encourage farmers to use water more efficiently. Also for countries not short of water there seems to be room for improvement (Seckler et al., 1998).

An increase in water price, for instance by a tax, would lead to the adoption of improved irrigation technology (e.g., Dinar and Yaron, 1992). The water saved could be used in other sectors, for which the value is much higher. In this paper, we do not look at a reallocation of water, but we do look at a reallocation of water-intensive products. National and international markets of agricultural products would be affected. A complete understanding of a water pricing policy is therefore impossible without understanding the international markets for food and other agricultural products, such as textiles.

There would be strong opposition against higher water prices, especially in water scarce regions. In many regions, water use is even subsidized. This is partly because of desired food self-sufficiency (Ahmad, 2000). However, food demand could be met by importing more water-intensive food from water abundant countries, and producing and exporting commodities that are less water-intensive. The water embedded in commodities is also known as virtual water (Allan, 1992 and 1993). So far, few studies provide estimates of global virtual water trade (see e.g. Chapagain and Hoekstra, 2004). Changes in water prices would affect virtual water trade. To our knowledge, this has not been investigated in a multi-region, multisector general equilibrium model.

Rosegrant et al. (2002) and Fraiture, Cai, Amarasinghe, Rosegrant and Molden (2004) use partial equilibrium models. Our general equilibrium approach allows for a richer set of economic feedbacks and for a complete assessment of the welfare implications. The analysis is based on countries' total renewable water resources and differences in water productivity. Growing wheat in North Africa requires more water than growing it in Germany. Also, different crop types have different crop water requirements; and regions grow different crop varieties. The production of a ton of rice is e.g. more water intensive than the production of a ton of wheat. Berrittella, Hoekstra, Rehdanz, Roson and Tol (2005) use GTAP-W, a computable general equilibrium (CGE) model including water resources, to analyze the

\footnotetext{
${ }^{1}$ Number is taken from AQUASTAT.
} 
economic impact of restricted water supply for water short regions. In contrast, this study is concerned with demand management, using a price rather than quantity instrument to regulate water use. In economic theory, under certainty, price and quantities are their duals, and price and quantity instruments have the same effect. However, the politics of prices and quantities are very different. Moreover, quantity instruments are, for all practical purposes, limited to primary production, whereas price instruments can be used at production as well as at consumption levels.

In this paper, we present the GTAP-W model and illustrate its potential application to water pricing policies. We use arbitrary water tax scenarios, as our main concern is methodological. We aim to demonstrate that water tax policies would generate spillover effects for economic activities and water consumption in other industries and regions than taxed. This analysis complements the one in Berrittella et al. (2005), in which we use the same model for different policy simulations.

Section 2 reviews the literature on water pricing. Section 2 also shows that our approach is complementary to what other people have done, as the price for economic comprehensiveness is a lack of detail in production and space. Section 3 presents the model used and the data on water resources and water use. The basic model and the corresponding data can be purchased from the Global Trade and Analysis Project (http://www.gtap.agecon.purdue.edu/). The water data can be downloaded at: http://www.fnu.zmaw.de/GTAP-EF-W.5680.0.html. Section 4 discusses four alternative scenarios. Section 5 presents results. Section 6 concludes.

\section{$2 \quad$ Previous studies}

Problems in the water sector are mostly caused by the large difference between the private and the social price of water. The difference is due to policy failures (subsidies), institutional failures (lack of well defined and enforced land and water rights) and market failures (environmental costs that are not internalized). A number of studies investigate the role of water price policies to allocate water resources more efficiently, equitably and sustainably. They differ with respect to study area (cross-country, national, regional) and sector analyzed (residential, industry, agriculture). Some studies have looked at the implementation and objectives of price policies in the water sector (e.g. Ahmad, 2000; Dinar and Subramanian, 1998; Jones, 1998; Rogers, Silva \& Bhatia, 2002). Other studies have analyzed the economic value of water, the costs of its provision and the price for its use (Rogers, Silva \& Bhatia, 1998; Ward and Michelsen, 2002; Young, 2005).

In order to obtain insights from alternative water policy scenarios on the allocation of water resources, partial and general equilibrium models have been used. While partial equilibrium analysis focus on the sector affected by a policy measure assuming that the rest of the economy is not affected, general equilibrium models consider other sectors or regions as well to determine the economy-wide effect. Most of the studies using either of the two approaches analyze pricing of irrigation water only (for an overview of this literature see Johannson, Tsur, Roe, Doukkali \& Dinar, 2002). Rosegrant et al. (2002) use the IMPACT-Water model to estimate demand and supply of food and water to 2025. Fraiture et al. (2004) extend this to include virtual water trade, using cereals as an indicator. Their results suggest that the role of virtual water trade is modest. While the IMPACT-Water model covers a wide range of agricultural products and regions, other sectors are excluded; it is a partial equilibrium model.

Studies using general equilibrium approaches are generally based on data for a single country or region assuming no effects for the rest of the world of the implemented policy. Decaluwe, Patry and Savard (1999) analyze the effect of water pricing policies on demand and supply of water in Morocco. Daio and Roe (2003) use an intertemporal CGE model for Morocco 
focusing on water and trade policies. Seung, Harris, Eglin and Netusil (2000) use a dynamic CGE model to estimate the welfare gains of reallocating water from agriculture to recreational use for the Stillwater National Wildlife Refuge in Nevada. For the Arkansas River Basin, Goodman (2000) shows that temporary water transfers are less costly than building new dams. Gómez, Tirado and Rey-Maquieira (2004) analyze the welfare gains by improved allocation of water rights for the Balearic Islands. Letsoalo et al. (forthcoming) study the effects of tax reform on water use, economic growth, and income distribution in South Africa.

Berrittella et al. (forthcoming) are an exception, using a multi-country CGE model including water resources (GTAP-W). They analyze the economic impact of restricted water supply for water-short regions. They contrast a market solution, where water owners can capitalize their water rent, to a non-market solution, where supply restrictions imply productivity losses. They show that water supply constrains could improve allocative efficiency, as agricultural markets are heavily distorted. The welfare gain may more than offset the welfare losses due to the resource constraint. In contrast to Berrittella et al. (forthcoming), this study is concerned with demand management (rather than with changes in water supply); this paper investigates the economic implications of water pricing policies.

\section{$3 \quad$ Modeling framework and data}

To assess the systemic, general equilibrium effects on water resource demand induced by different policy scenarios, we use a multi-region world CGE model, called GTAP-W. The model is a refinement of the GTAP model $^{2}$ (Hertel, 1997) in the version modified by Burniaux and Truong ${ }^{3}$ (2002). Basically, in the GTAP-W model a finer industrial and regional aggregation level, respectively, 17 sectors and 16 regions, is considered, and water resources, as non-market goods, have been modeled. ${ }^{4}$ Some characteristics are given in Table A1 in the Annex. The model is based on 1997 data.

As in all CGE models, the GTAP-W model makes use of the Walrasian perfect competition paradigm to simulate adjustment processes. Industries are modeled through a representative firm, which maximizes profits in perfectly competitive markets. The production functions are specified via a series of nested CES functions (see Berrittella et al., forthcoming, for more detailed information). Domestic and foreign inputs are not perfect substitutes, according to the so-called "Armington assumption", which accounts for product heterogeneity.

A representative consumer in each region receives income, defined as the service value of national primary factors (natural resources, land, labour and capital). Capital and labour are perfectly mobile domestically, but immobile internationally. Land (imperfectly mobile) and natural resources are industry-specific. The national income is allocated between aggregate household consumption, public consumption and savings (see Berrittella et al., forthcoming, for more detailed information). The expenditure shares are generally fixed, which amounts to

\footnotetext{
${ }^{2}$ The GTAP model is a standard CGE static model distributed with the GTAP database of the world economy (www.gtap.org). For detailed information see Hertel (1997) and the technical references and papers available on the GTAP website.

${ }^{3}$ Burniaux and Truong (2002) developed a variant of the model, called GTAP-E. The model is best suited for the analysis of energy markets and environmental policies. There are two main changes in the basic structure. First, energy factors are separated from the set of intermediate inputs and inserted in a nested level of substitution with capital. This allows for more substitution possibilities. Second, database and model are extended to account for $\mathrm{CO}_{2}$ emissions related to energy consumption.

${ }^{4}$ The 16 sectors are rice; wheat; other cereals and crops; vegetables and fruits; animals; forestry; fishing; coal mining; oil; natural gas extraction; refined oil products; electricity; water collection, purification and distribution services; energy intensive industries; other industry and services; market services; non-market services.
} 
saying that the top-level utility function has a Cobb-Douglas specification. Private consumption is split in a series of alternative composite Armington aggregates. The functional specification used at this level is the Constant Difference in Elasticities (CDE) form: a nonhomothetic function, which is used to account for possible differences in income elasticities for the various consumption goods. A money metric measure of economic welfare, the equivalent variation, can be computed from the model output.

In the GTAP model and its variants, two industries are treated in a special way and are not related to any region. International transport is a world industry, which produces the transportation services associated with the movement of goods between origin and destination regions, thereby determining the cost margin between f.o.b. and c.i.f. prices. Transport services are produced by means of factors submitted by all countries, in variable proportions. In a similar way, a hypothetical world bank collects savings from all regions and allocates investments so as to achieve equality of expected future rates of return.

In our modeling framework, water is combined with the value-added-energy nest and the intermediate inputs (see Berrittella et al., forthcoming, for more detailed information). As in the original GTAP model, there is no substitutability between intermediate inputs and valueadded for the production function of tradeable goods and services. In the benchmark equilibrium, water supply is supposed to be unconstrained, so that water demand is lower or equal than water supply, and the price for water is zero. Water is supplied to the agricultural industry, which includes primary crop production and livestock, and to the water distribution services sector, which delivers water to the rest of the economic sectors. ${ }^{5}$

The key parameter for the determination of regional water use is the water intensity coefficient. This is defined as the amount of water necessary for sector $j$ to produce one unit of commodity. ${ }^{6}$ To estimate water intensity coefficients, we first calculated total water use by commodity and country for the year 1997. For the agricultural sector the FAOSTAT database provided information on production of primary crops and livestock. This includes detailed information on different crop types and animal categories. Information on water requirements for crop growth and animal feeding was taken from Chapagain and Hoekstra (2004). ${ }^{7}$ The water requirement includes both the use of blue water (ground and surface water) as well as green water (moisture stored in soil strata). For crops it is defined as the sum of water needed for evapotranspiration, from planting to harvest, and depends on crop type and region. This procedure assumes that water is not short and no water is lost by irrigation inefficiencies. For animals, the virtual water content is mainly the sum of water needed for feeding and drinking. The water intensity parameter for the water distribution sector is based on the country's industrial and domestic water use data provided by AQUASTAT. ${ }^{8}$

We make the link between output levels and water demand sensitive to water prices, by assuming that more expensive water brings about rationalization in usage and substitution with other factors. The actual capability of reducing the relative intensity of water demand is industry-specific, and captured by an industrial water price elasticity parameter (Table 1).

\section{Table 1 about here}

\footnotetext{
${ }^{5}$ Note that distributed water can have a price, even if primary water resources are in excess supply.

${ }^{6}$ This refers to water directly used in the production process, not to the water indirectly needed to produce other input factors.

${ }^{7}$ This information is provided as an average over the period from 1997 to 2001 . By making use of this data we assume that water requirements are constant at least in the short term.

${ }^{8}$ This information is based on data for 2000. By making use of this data we assume that domestic and industrial water uses in 2000 are the same as in 1997.
} 
We run four alternative simulation exercises, each dealing with the economic impacts of water pricing policies.

In the base scenario (scenario 1), we impose a water charge of $\$ 10$ mln per $10^{9} \mathrm{~m}^{3}$ of water for all users. This is equivalent to a price increase of $\$ 1$ per cubic meter of water. The aim of this scenario is to test how much water saving can be achieved, and at what economic cost. As a first sensitivity analysis, in the second scenario, we lower the price to $\$ 0.5 / \mathrm{m}^{3}$.

The value of water differs not only between countries but also between the various sectors. Prices for agricultural water use are generally lower compared to domestic water use; most expensive is industrial water use (see e.g. Ahmad, 2000; Dinar and Subramanian, 1998). Variable costs for agricultural water use, for example, range between zero and $\$ 0.39$ per $\mathrm{m}^{3}$. Compared to those numbers, our water taxes are small. This has two reasons. First, farmers grow crops with three different sources of water; rain, soil moisture and irrigation water. However, they pay for irrigation water only. The average price for all three uses is, therefore, small. We do not differentiate between water sources because of data limitations. Second, industrial water use is defined as the water use by self-supplied industries, not connected to any distribution network. "Domestic" water use is computed as the total amount of water supplied by public distribution networks, and usually includes the withdrawal by industries connected to public networks. However, in the model, all industrial and domestic water use, connected to a public network or not, is included as customers of the water distribution network.

Scenario 3 is a variant of scenario 1 . Water taxes are introduced in water-short regions only, viz. North Africa (NAF), South Asia (SAS), the United States (USA) and China (CHI). These regions use more groundwater than is recharged (cf. Berrittella et al., forthcoming).

In scenarios 1-3, water is taxed when used in production. In scenario 4, final consumption is taxed, proportional to the water used in the production of the consumption goods. We apply a water charge of $\$ 10 \mathrm{mln}$ per $10^{9} \mathrm{~m}^{3}$ of water.

In all scenarios, the revenue of the water tax is redistributed, lump sum, to the representative household.

\section{$5 \quad$ Simulation results}

Results for all scenarios described in section 4 are presented in Tables 2 to 5 , reporting water demand, virtual water trade balance, GDP, trade balance and welfare. The virtual water trade balance reports, similar to the trade balance, the difference between a region's exports to its imports measured in water quantities.

In scenario 1, reported in Table 2, we simulate a water tax of $\$ 10 \mathrm{mln}$ per $10^{9} \mathrm{~m}^{3}$ of water. The increase in water prices leads to a decrease in water demand in all regions, except in Western Europe. This region has a low water-intensity and shows little sensitivity to changes in prices for water. Consequently, although water prices increase, agricultural production is raised, and water-intensive products are exported to other regions. The virtual water trade balance is positive for Western Europe. North Africa exhibits the highest reduction in water demand. This is because the water-intensity of this region is high. The water tax leads to a net increase in virtual water imports in regions that are relatively water-intensive, such as North Africa, Sub-Saharan Africa and South Asia. These are also the regions with limited water resource availability. Water-short countries partly meet their demand for water-intensive products by 
importing them. Global welfare falls due to the increase of water prices and the restriction of a scarce resource. However, welfare losses are not universal; some regions gain as their competitive position improves, such as the USA and Western Europe.

Applying the water tax only to agricultural sectors (results not shown), total water demand is higher than in the first scenario, because there is no change in the water charge for the water distribution services sector. The more water-intensive the agricultural sectors are, the higher is the deficit in terms of virtual water trade balance. Overall, taxing agricultural water use only is a reasonably effective policy. It deviates from the optimum of taxing all water use, but the welfare loss is limited.

The scenario results depend to some extend on the water price elasticity (results not shown). If there is no flexibility in water intensity at the level of farms and water distribution companies, countries cannot improve their water efficiency in domestic production. The global water demand is higher (decreases less) than in scenario 1. On the regional level the change in demand differs; demand decreases less, increases rather than decreases, or increases more depending on the regions' water price elasticity as well as the water- intensity coefficient. The global welfare decreases more, because the resource constraint is more stringent. Although the regional pattern is the same as in scenario 1, regions with higher price elasticities suffer more if they cannot improve their water efficiency in domestic production.

\section{Table 2 about here}

Table 3 reports the simulation results of scenario 2, where water is taxed at $\$ 5 \mathrm{mln}$ per $10^{9} \mathrm{~m}^{3}$. As expected, water demand falls, but less so than in scenario 1. Comparing the two sets of results, the reduction of water demand is slightly less than linear in the water tax. Water price increase is half the amount of scenario 1, but water demand decreases more than $50 \%$ for most regions. Welfare falls in the more water intensive countries, such as North Africa and the Middle East, but less so than in scenario 1. The opposite occurs for more water efficient regions, such as Western Europe and the USA. At world level, welfare falls, but a factor 7 less so than in scenario 1 ( $-\$ 125 \mathrm{mln}$ compared to $-\$ 846 \mathrm{mln})$.

\section{Table 3 about here}

In scenario 3, we increase the water charges only for water-short regions, viz. North Africa, China, the USA and South Asia (see Table 4). The water demand decreases in these four regions, the more so in the less water efficient ones, such as North Africa. In terms of virtual water trade, as expected, an increase in the water price leads to an increase in virtual water import in the constrained regions, and to a decrease in virtual water exports. On the other hand, a deficit in terms of virtual water trade is not always accompanied by a negative variation in the trade balance. For example, in North Africa, South Asia and China, the trade balance improves. The USA, South Asia and China loose in terms of welfare, relative to scenario 1. On the other hand, North Africa gains because the increase of the imports of water-intensive goods is less expensive than in scenario 1 . The global welfare decreases in scenario 3, but less so than in scenario 1 , as water prices increase in some regions only. Increasing water charges in four regions reduces the world welfare by half the amount an increase in water rent for all 16 regions would lead to. Furthermore, excluding the USA from the list of water-restricted countries affects water savings only slightly (from $2.7 \%$ to $2.6 \%$ ), 
but reduces the world welfare loss substantially, from a welfare loss of $\$ 413 \mathrm{mln}$ to a welfare loss of \$281 mln (results not shown).

\section{Table 4 about here}

In scenario 4, final consumption of water-intensive commodities and services is taxed instead of taxation of factor inputs. Taxing water in this way leads to a decrease in the demand for water in all regions. In this scenario, the reductions in water resource uses are more uniform amongst regions than in scenario 1, and global water demand changes less. Furthermore, changes in virtual water trade are substantially lower. Unlike in any other scenario, global welfare increases. Especially Western Europe, Japan and South Korea gain more, while the Middle East and Sub-Saharan Africa are the main losers. However, compared to scenario 1, welfare changes are generally less negative in many regions. The more a region imports water-intensive commodities, the more that region gains compared to the first scenario. This shows that it matters how the costs of water resource use are internalized, as this determines the options for substituting away from water, as well as the distribution of the burden.

\section{Table 5 about here}

\section{Discussion and conclusion}

In this paper, we present a computable general equilibrium model of the world economy with water as an explicit factor of production. We use the model to test water taxes under different scenarios. In the base scenario, we simulate a water charge of $\$ 10 \mathrm{mln}$ per $10^{9} \mathrm{~m}^{3}$ of water. As expected, the water demand decreases in many regions, but some regions find it profitable to raise the production of water-intensive commodities in order to export them. The world as a whole is worse off, although some countries gain as their competitive position improves. Water demand falls less than linear in the water tax; welfare losses are more than linear in the water tax. The impact of a water tax is more pronounced if it is harder to improve water efficiency. Furthermore, any water price policy should take into account who and what is taxed. Water taxes in agriculture drive most of the effects, and virtually all of the trade effects. A tax in water-scarce regions only would lead to a shift in agricultural trade, and an increase in water demand elsewhere. A water tax in some countries, particularly the USA, contributes little to water savings but substantially to welfare losses. There is a clear trade-off between water savings and welfare change. A tax on the final consumption of water rather than on the use of water in production would be less effective in reducing water use, but would be less costly; while the distributional and trade effects are very different.

For some world regions, the water supply is already critical. Rapid population growth and increasing consumption per capita has further aggregated the problem. An additional reason for concern is climate change. Today, most problems in the water sector are caused by large differences between the private and the social price of water. Although an optimal policy would include all water using sectors, a water tax on agriculture, the main water user, has a significant impact on water savings already. Such a policy would considerably reduce the gap between the private and the social cost of water. For water-short countries, it would be beneficial if water is not taxed abroad. Water taxes in water-rich countries would further increase market prices for agricultural goods and raise the price of imported water-intensive products. To limit the negative impact of rising world market prices for water-intensive products, a water tax should be accompanied by policies promoting the substitutes for water- 
intensive products, improved irrigation, limiting water leakage, and improved efficiency. Another important issue is the crop mix. A different mix with less water demanding crops, which are perhaps also more adapted to heat, might reduce water demand further. Trade liberalization might help as well, as it stimulates substitution.

The analysis establishes two things. Firstly, domestic policies to conserve water, here implemented by a water tax, has ramifications for international trade. As a result, national water policies are interconnected and should, at the least, not be set in ignorance of other countries' water policies. Secondly, the effects of water policy on national economies and international trade can gainfully be studied with a computable general equilibrium model. The data used in this paper to extend the GTAP-CGE, are in the public domain.

This analysis needs to be extended in several ways and a number of limitations apply. First, we have not been able to allocate industrial water use to its different users. We rather used a simplifying assumption that water for domestic and industry use is supplied by the water service sector. Second, we consider regional water supply, implicitly assuming that there is a perfect water market and costless water transport within each region. Sector-specific water resources allow for sub-regional differentiation of water resources, but only to a limited extent. Third, we were not able to differentiate between the different qualities of water supplied. Some, but not all, of the difference is captured by defining sector-specific water. Fourth, in our model we assume that water is used efficiently and no water is wasted. The water intensity coefficient captures some differences, but these differences do not respond to price or other signals, except to the price of water. Fifth, for the agricultural sector, we used irrigation water plus rainfall, without distinction; water use is gross water use, ignoring evapotranspiration by crops. Sixth, we nested water at the upper level in the production function of the water intensive goods and services, so that water cannot be substituted with specific inputs in the production processes. Seventh, we used a single data set for water use and water resources, ignoring the uncertainties in the data. All this is deferred to future research.

\section{Acknowledgements}

This paper benefited greatly from comments by an anonymous referee. We had useful discussions about the topics of this paper with Francesco Bosello, Alvaro Calzadilla, Hom Pant, Jian Zhang and Yuan Zhou. Also, we would like to thank Arjen Hoekstra for directing us to the UNESCO-IHE publication on water footprints of nations and providing the associated data. The Michael Otto Foundation for Environmental Protection, the Hamburg University Innovation Fund, and the Princeton Environmental Institute provided welcome financial support. All errors and opinions are ours. 


\section{$\underline{\text { Appendix }}$}

Table A1. Regional characteristics

\begin{tabular}{|c|c|c|c|c|c|c|c|c|c|}
\hline & \multicolumn{2}{|c|}{ PopulationGDP/cap } & \multicolumn{2}{|c|}{$\begin{array}{l}\text { Renewable water } \\
\text { resource }\end{array}$} & Water use & \begin{tabular}{|c|} 
Water \\
intensity in \\
agriculture
\end{tabular} & $\begin{array}{c}\text { Water } \\
\text { intensity } \\
\text { other }^{d}\end{array}$ & $\begin{array}{l}\text { Water } \\
\text { imports }\end{array}$ & $\begin{array}{l}\text { Water } \\
\text { exports }\end{array}$ \\
\hline & mln & $\$$ & $\begin{array}{c}10^{9} \mathrm{~m}^{3} \\
\text { per year }\end{array}$ & $\mathrm{m}^{3} /$ person $^{b}$ & $\begin{array}{c}10^{9} \mathrm{~m}^{3} \\
\text { per year }\end{array}$ & $\mathrm{m}^{3} / \$$ & $\mathrm{~m}^{3} / \$$ & $10^{9} \mathrm{~m}^{3}$ & $10^{9} \mathrm{~m}^{3}$ \\
\hline USA & 276 & 28786 & 3069 & 11120 & 479 & 2.9 & 3.7 & 57 & 125 \\
\hline CAN & 30 & 20572 & 2902 & 96733 & 46 & 4.3 & 5.2 & 8 & 51 \\
\hline WEU & 388 & 24433 & 2227 & 5740 & 227 & 2.6 & 3.5 & 256 & 96 \\
\hline JPK & 172 & 35603 & 500 & 2907 & 107 & 1.4 & 1.6 & 82 & 0 \\
\hline ANZ & 22 & 21052 & 819 & 37227 & 26 & 4.1 & 1.2 & 3 & 30 \\
\hline CEE & 121 & 2996 & 494 & 4083 & 60 & 3.3 & 13.6 & 19 & 6 \\
\hline FSU & 291 & 1556 & 4730 & 16254 & 284 & 9.1 & 28.0 & 27 & 61 \\
\hline MDE & 227 & 3150 & 483 & 2128 & 206 & 4.9 & 6.8 & 35 & 19 \\
\hline CAM & 128 & 2938 & 1183 & 9242 & 101 & 5.2 & 13.6 & 25 & 31 \\
\hline LAM & 332 & 4830 & 12246 & 36886 & 164 & 3.9 & 5.9 & 35 & 68 \\
\hline SAS & 1289 & 416 & 3685 & 2859 & 918 & 9.8 & 47.5 & 21 & 25 \\
\hline SEA & 638 & 4592 & 5266 & 8254 & 279 & 10.1 & 12.8 & 58 & 35 \\
\hline $\mathrm{CHI}$ & 1274 & 790 & 2897 & 2274 & 630 & 3.6 & 38.5 & 33 & 16 \\
\hline NAF & 135 & 1284 & 107 & 793 & 95 & 8.5 & 39.5 & 27 & 4 \\
\hline SSA & 605 & 563 & 4175 & 6901 & 113 & 11.4 & 6.4 & 14 & 132 \\
\hline ROW & 42 & 3338 & 2984 & 71048 & 75 & 4.7 & 2.7 & 6 & 8 \\
\hline
\end{tabular}

a 2001 estimates taken from Aquastat.

${ }^{\mathrm{b}} \mathrm{UN}$ criterion for water resource scarcity degree: slightly scarce (1700-3000), middle scarce (1000-1700), severe scarcity (500-1000) and most severe scarcity $(<500)$.

${ }^{c}$ Average water intensity covering crop/plant growth and animal production measured in water use/\$ output. Numbers differ considerably between countries and sectors. Note that water use includes the use of different kind of sources; rain, soil moisture and irrigation water. However, farmers pay for irrigation water only.

${ }^{\mathrm{d}}$ Note that in some countries only a low number of persons is connected to a distribution network. In others a number of self-supplied industries are not connected. However, both are included as users of the services the water distribution network provides. As a consequence, water use per $\$$ of output is overstated in the above table. 


\section{References}

Ahmad, M. (2000). Water pricing and markets in the Near East: policy issues and options, Water Policy 2 229-242.

Allan, J.A. (1992). Fortunately there are substitutes for water otherwise our hydro-political futures would be impossible. In: Proceedings of the Conference on Priorities for Water Resources Allocation and Management : Natural Resources and Engineering Advisers Conference, Southampton, July 1992, pp. 13-26.

Allan, J.A. (1993). Overall perspectives on countries and regions. In: Rogers, P. and Lydon, P. (Eds.) Water in the Arab World: Perspectives and Prognoses, Cambridge, Massachusetts, pp. 65-100.

Berrittella, M., Hoekstra, A., Rehdanz, K., Roson, R. \& Tol, R.S.J. (forthcoming). The economic impact of restricted water supply: A computable general equilibrium analysis, Water Research.

Burniaux, J.-M. \& Truong, T.P. (2002). GTAP-E: An energy environmental version of the GTAP model, GTAP Technical Paper n.16.

Chapagain, A.K. \& Hoekstra, A.Y. (2004). Water Footprints of Nations, Value of Water Research Report Series No. 16, UNESCO-IHE Delft, The Netherlands.

Decaluwé, B., Patry, A. \& Savard, L. (1999). When water is no longer heaven sent: Comparative pricing analysis in a AGE model, Working Paper 9908, CRÉFA 99-05, Départment d'économique, Université Laval.

Diao, X. \& Roe, T. (2003). Can a water market avert the "double-whammy" of trade reform and lead to a "win-win" outcome? Journal of Environmental Economics and Management 45 708-723.

Dinar, A. \& Yaron, D. (1992). Adoption and Abandonment of Irrigation Technologies. Agricultural Economics 6 315-32.

Dinar, A. \& Subramanian, A. (1998). Policy implications from water pricing experiences in various countries, Water Policy 1 239-250.

Fraiture, C. de, Cai, X., Amarasinghe, U., Rosegrant, M. \& Molden, D. (2004). Does international cereal trade save water? The impact of virtual water trade on global water use. Comprehensive Assessment Research Report 4, Colombo, Sri Lanka.

Gómez, C.M., Tirado, D. \& Rey-Maquieira, J. (2004). Water exchange versus water work: Insights from a computable general equilibrium model for the Balearic Islands, Water Resources Research 42 W10502 10.1029/2004WR003235.

Goodman, D.J. (2000). More reservoir or transfer? A computable general equilibrium analysis of projected water shortages in the Arkansas River Basin, Journal of Agricultural and Resource Economics 25 (2) 698-713.

Hertel, T.W. (1997). Global Trade Analysis: Modeling and applications, Cambridge University Press, Cambridge.

Intergovernmental Panel on Climate Change (2001). Impacts, adaptation, and vulnerability. Contribution of Working Group II to the Third Assessment Report of the Intergovernmental Panel on Climate Change Edited by McCarthy, J., Canziani, O., Leary, N., Dokken, D. and White, K., Cambridge University Press, Cambridge.

Johannson, R.C., Tsur, Y., Roe, T.L., Doukkali, R. \& Dinar, A. (2002). Pricing irrigation water: A review of theory and practice, Water Policy 4 173-199. 
Jones, T. (1998). Recent developments in the pricing of water services in OECD countries, Water Policy 1 637-651.

Letsoalo, A., Blignaut, J., de Wet, T., de Wit, M., Hess, S., Tol, R.S.J. \& J. van Heerden, J. (forthcoming). 'Triple Dividends of Water Consumption Charges in South Africa', Water Resources Research.

Rogers, P., de Silva, R. \& Bhatia, R. (1998). Water as a social and economic good: How to put the principle into practice, TAC Background Paper No. 2, Global Water Partnership, Stockholm.

Rogers, P., de Silva, R. \& Bhatia, R. (2002). Water is an economic good: How to use prices to promote equity, efficiency, and sustainability, Water Policy 4 1-17.

Rosegrant, M.W., Cai, X. \& Cline, S.A. (2002). World water and food to 2025: Dealing with scarcity. International Food Policy Research Institute, Washington.

Seckler, D., Amarasinghe, U., Molden, D., Silve, R. de \& Barker, R. (1998). World water demand and supply, 1990 to 2025: Scenarios and issues. Research Report 19. International Water Management Institute, Colombo, Sri Lanka.

Seung, C.K., Harris, T.R., Eglin, J.E. \& Netusil, N.R. (2000). Impacts of water reallocation: A combined computable general equilibrium and recreation demand model approach, The Annals of Regional Science 34 473-487.

Ward, F.A. \& Michelsen, A. (2002). The economic value of water in agriculture: Concepts and policy applications, Water Policy 4 423-446.

Young, R.A. (2005). Determining the Economic value of water: Concepts and methods, Resources for the Future, Washington, DC. 
Figures and Tables

Table 1. Water price elasticities

\begin{tabular}{|l|l|r|r|}
\hline & \multicolumn{1}{|c|}{ Country region } & $\begin{array}{c}\text { Agricul } \\
\text { tural } \\
\text { sectors }\end{array}$ & $\begin{array}{r}\text { Water distribution } \\
\text { services }\end{array}$ \\
\hline USA & United States & -0.14 & -0.72 \\
\hline CAN & Canada & -0.08 & -0.53 \\
\hline WEU & Western Europe & -0.04 & -0.45 \\
\hline JPK & Japan and Korea & -0.06 & -0.45 \\
\hline ANZ & Australia and New & -0.11 & -0.67 \\
& Zealand & & \\
\hline EEU & Eastern Europe & -0.06 & -0.44 \\
\hline FSU & Former Soviet Union & -0.09 & -0.67 \\
\hline MDE & Middle East & -0.11 & -0.77 \\
\hline CAM & Central America & -0.08 & -0.53 \\
\hline SAM & South America & -0.12 & -0.80 \\
\hline SAS & South Asia & -0.11 & -0.75 \\
\hline SEA & Southeast Asia & -0.12 & -0.80 \\
\hline CHI & China & -0.16 & -0.80 \\
\hline NAF & North Africa & -0.07 & -0.60 \\
\hline SSA & Sub-Saharan Africa & -0.15 & -0.80 \\
\hline ROW & Rest of the world & -0.20 & -0.85 \\
\hline SOurc: & O &
\end{tabular}

Source: Our elaboration from Rosegrant et al.(2003). 
Table 2. Scenario 1 : Uniform change in the regional water rent (\$10 mln per $10^{9} \mathrm{~m}^{3}$ of water)

\begin{tabular}{|c|c|c|c|c|c|}
\hline & $\begin{array}{c}\text { Water } \\
\text { demand } \\
(\%)\end{array}$ & $\begin{array}{c}\text { Virtual water } \\
\text { trade balance } \\
\text { (change in } \\
\left.10^{9} \mathrm{~m}^{3}\right)\end{array}$ & GDP (\%) & $\begin{array}{c}\text { Trade } \\
\text { balance } \\
\text { (change in } \\
\text { mln \$) }\end{array}$ & \begin{tabular}{|c|}
$E V$ \\
welfare \\
(change in \\
mln \$)
\end{tabular} \\
\hline USA & -1.45 & 4.31 & -0.003 & -4719 & 1766 \\
\hline CAN & -3.69 & -1.99 & 0.016 & -72 & 449 \\
\hline WEU & 0.45 & 24.78 & 0.011 & -4863 & 1135 \\
\hline JPK & -0.19 & 4.97 & 0.001 & -3961 & 816 \\
\hline ANZ & -1.23 & -0.47 & 0.008 & -197 & 394 \\
\hline EEU & -3.54 & 2.27 & -0.028 & 663 & -280 \\
\hline FSU & -12.20 & -6.85 & -0.024 & 1092 & -712 \\
\hline MDE & -6.63 & -0.89 & -0.024 & 1913 & -1448 \\
\hline CAM & -4.10 & -1.78 & 0.012 & 57 & 102 \\
\hline SAM & -0.62 & 4.02 & 0.004 & 93 & 583 \\
\hline SAS & -5.25 & -5.01 & -0.069 & 2644 & -842 \\
\hline SEA & -2.73 & 3.49 & -0.029 & 1862 & -781 \\
\hline CHI & -7.58 & 2.37 & -0.011 & 2006 & -365 \\
\hline NAF & -19.25 & -3.72 & -0.119 & 1097 & -1123 \\
\hline SSA & -6.85 & -25.58 & -0.115 & 2278 & -428 \\
\hline ROW & -1.73 & 0.07 & -0.004 & 106 & -112 \\
\hline
\end{tabular}


Table 3. Scenario 2 : Uniform change in the regional water rent (\$5 mln per $10^{9} \mathrm{~m}^{3}$ of water)

\begin{tabular}{|l|r|r|r|r|r|}
\hline & $\begin{array}{c}\text { Water } \\
\text { demand } \\
\mathbf{( \% )}\end{array}$ & $\begin{array}{c}\text { Virtual water } \\
\text { trade balance } \\
\text { (change in } \\
\mathbf{1 0}_{\mathbf{9}} \mathbf{~ m}^{\mathbf{3}} \mathbf{\text { GDP }}\end{array}$ & $\begin{array}{c}\text { Trade } \\
\text { balance } \\
\text { (change in } \\
\text { mln \$) }\end{array}$ & $\begin{array}{c}\text { EV } \\
\text { welfare } \\
\text { (change in } \\
\text { mln \$) }\end{array}$ \\
\hline USA & -0.76 & 1.97 & -0.001 & -2247 & 830 \\
\hline CAN & -1.84 & -0.97 & 0.009 & -29 & 222 \\
\hline WEU & 0.19 & 12.29 & 0.005 & -2278 & 477 \\
\hline JPK & -0.10 & 2.53 & 0.000 & -1873 & 372 \\
\hline ANZ & -0.72 & -0.30 & 0.004 & -93 & 187 \\
\hline EEU & -1.86 & 1.12 & -0.013 & 330 & -139 \\
\hline FSU & -6.50 & -3.40 & -0.007 & 522 & -307 \\
\hline MDE & -3.33 & -0.44 & -0.008 & 911 & -661 \\
\hline CAM & -2.04 & -0.86 & 0.008 & 26 & 63 \\
\hline SAM & -0.34 & 1.89 & 0.002 & 62 & 266 \\
\hline SAS & -2.75 & -2.33 & -0.020 & 1235 & -320 \\
\hline SEA & -1.35 & 1.69 & -0.012 & 874 & -355 \\
\hline CHI & -4.31 & 1.16 & -0.004 & 995 & -173 \\
\hline NAF & -8.90 & -1.54 & -0.013 & 474 & -407 \\
\hline SSA & -3.35 & -12.86 & -0.040 & 1039 & -127 \\
\hline ROW & -0.86 & 0.03 & -0.002 & 53 & -53 \\
\hline
\end{tabular}


Table 4. Scenario 3: Uniform change in regional water rent for water short countries (\$10 mln per $10^{9} \mathrm{~m}^{3}$ of water)

\begin{tabular}{|l|r|r|r|r|r|}
\hline & $\begin{array}{c}\text { Water } \\
\text { demand } \\
\mathbf{( \% )}\end{array}$ & $\begin{array}{c}\text { Virtual water } \\
\text { trade balance } \\
\text { (change in } \\
\mathbf{1 0}_{\mathbf{9}} \mathbf{~ m}^{\mathbf{3}} \mathbf{\text { GDP }}\end{array}$ & $\begin{array}{c}\text { Trade } \\
\text { balance } \\
\text { (change in } \\
\text { mln \$) }\end{array}$ & $\begin{array}{c}\text { EV } \\
\text { welfare } \\
\text { (change in } \\
\text { mln \$) }\end{array}$ \\
\hline USA & -2.56 & -6.22 & 0.002 & -518 & 782 \\
\hline CAN & 1.87 & 2.54 & -0.001 & -179 & 101 \\
\hline WEU & 0.61 & 5.12 & 0.003 & -2817 & 780 \\
\hline JPK & 0.19 & 0.57 & -0.005 & -1567 & -66 \\
\hline ANZ & 4.76 & 3.36 & 0.003 & -125 & 152 \\
\hline EEU & 0.24 & 0.30 & 0.005 & -141 & 35 \\
\hline FSU & 0.49 & 1.22 & -0.001 & -166 & -38 \\
\hline MDE & 0.95 & 1.27 & -0.011 & -203 & -261 \\
\hline CAM & 0.74 & 1.38 & -0.009 & -30 & -58 \\
\hline SAM & 0.54 & 2.89 & 0.008 & -499 & 320 \\
\hline SAS & -5.62 & -9.68 & -0.069 & 2831 & -951 \\
\hline SEA & 0.15 & 1.51 & -0.003 & -6 & -117 \\
\hline CHI & -8.04 & -1.72 & -0.001 & 2360 & -416 \\
\hline NAF & -21.09 & -8.10 & -0.099 & 1222 & -818 \\
\hline SSA & 0.69 & 5.15 & 0.010 & -101 & 132 \\
\hline ROW & 0.19 & 0.42 & 0.002 & -61 & 12 \\
\hline
\end{tabular}


Table 5. Scenario 4: Water taxation on consumption

(\$10 mln per $10^{9} \mathrm{~m}^{3}$ of water)

\begin{tabular}{|l|r|r|r|r|r|}
\hline & $\begin{array}{c}\text { Water } \\
\text { demand } \\
\mathbf{( \% )}\end{array}$ & $\begin{array}{c}\text { Virtual water } \\
\text { trade balance } \\
\text { (change in } \\
\mathbf{1 0}^{\mathbf{9}} \mathbf{m}^{\mathbf{3}} \text { ) }\end{array}$ & & $\begin{array}{c}\text { Trade } \\
\text { balance } \\
\text { (change in } \\
\text { mln \$) }\end{array}$ & $\begin{array}{c}\text { EV } \\
\text { welfare } \\
\text { (change in } \\
\text { mln \$) }\end{array}$ \\
\hline USA & -2.10 & -2.19 & 0.000 & -3919 & 671 \\
\hline CAN & -3.08 & -1.54 & 0.007 & 44 & 29 \\
\hline WEU & -0.83 & -3.81 & 0.015 & -4609 & 2629 \\
\hline JPK & -0.53 & -0.13 & 0.009 & -4354 & 1998 \\
\hline ANZ & -2.67 & -1.36 & -0.001 & -46 & -96 \\
\hline EEU & -3.37 & -0.15 & -0.017 & 431 & -105 \\
\hline FSU & -7.44 & 0.01 & -0.015 & 1182 & -537 \\
\hline MDE & -1.72 & 0.39 & -0.032 & 1584 & -1092 \\
\hline CAM & -1.96 & 0.00 & 0.000 & 173 & -90 \\
\hline SAM & -1.32 & -0.81 & -0.009 & 357 & -392 \\
\hline SAS & -3.76 & 2.40 & -0.067 & 2602 & -755 \\
\hline SEA & -2.02 & 1.77 & -0.031 & 1963 & -453 \\
\hline CHI & -6.29 & -0.15 & -0.004 & 1585 & -201 \\
\hline NAF & -3.16 & 0.59 & -0.015 & 555 & -253 \\
\hline SSA & -3.12 & 4.99 & -0.079 & 2317 & -1049 \\
\hline ROW & -1.50 & 0.01 & -0.005 & 136 & -118 \\
\hline
\end{tabular}

